\title{
Influence of variety and season on the yield and nutritional quality of barley and wheat stubble in north-west Syria
}

\author{
S. Rihawi and T. Treacher \\ International Centre for Agricultural Research in the Dry Areas, PO Box 5466, Aleppo, Syria
}

\section{Introduction}

In west Asia and north Africa in the period between harvesting of cereals in June and about November, grazing of stubble is the most important source of nutrients for the flocks of small ruminants, particularly sheep which move from the steppe into the agricultural areas for the summer and autumn. Mating and the first part of pregnancy take place while the flocks are grazing stubble. Although the effects of the quality of harvested cereal straw on its intake have been extensively studied, we have found no published information on the effects of the composition of stubble on its quality as a source of nutrients for grazing ruminants.

\section{Material and methods}

In 1988 and 1989 quadrats were cut to ground level in stubble remaining after combine harvesting, with a cutting height of approximately $15 \mathrm{~cm}$, of four varieties of barley (Arabi Abiad, Beecher, C63 and EP/Apam), two varieties of durum wheat (Horani and Sham 3) and one variety of bread wheat (Sham 4). The cereals were planned after ploughing and harrowing, using a seed rate of $100 \mathrm{~kg} / \mathrm{ha}$ and applications of $50 \mathrm{~kg} / \mathrm{ha}$ of $\mathrm{P}_{2} \mathrm{O}_{5}$ at sowing and $50 \mathrm{~kg} / \mathrm{ha}$ of $\mathrm{NH}_{4} \mathrm{NO}_{3}$ in February.

In each variety 10 quadrats of $1 \mathrm{~m}^{2}$ were cut. The material collected within each quadrat was separated into stem, leaf and head to assess the amounts of these fractions and the total dry matter
(DM) present per unit area. The three fractions from the 10 quadrats were then bulked and analysed for crude protein (CP), ash, neutral-detergent fibre and in vitro digestibility measured as digestible organic matter in the DM (DOMD). In addition, the degradability of the stem and leaf fractions of the barley varieties was assessed from their rates of disappearance from polyester bags placed in the rumen of fistulated sheep with bags removed at 0,6 , $12,24,48,72$ and $96 \mathrm{~h}$.

\section{Results}

The rainfall was $504 \mathrm{~mm}$ in 1987/88 and $234 \mathrm{~mm}$ in 1988/89; the average rainfall in the area is $304 \mathrm{~mm}$. This had a major effect on the amount of stubble in the 2 years and on the proportions of stem and leaf (Table 1). There were no significant differences between varieties in total DM present or in the proportions of stem, leaf and head. The pattern of change in proportion of leaf and head between 1988 and 1989 was similar in all varieties, except C63 barley, which showed almost no change between the wet and dry years.

The changes in the proportions of stems, leaf and heads between the years resulted in a large increase in CP content (Table 2) in the dry year of 1989 (proportionately 0.55 for barley and 1.30 for wheat). The increase in DOMD content was small for barley (0.12) but large for wheat $(0.66)$. The large fall in stubble DM present in 1989 resulted in considerably

Table 1 Yields and composition of barley and wheat stubbles in 1988 and 1989

\begin{tabular}{|c|c|c|c|c|c|c|c|c|}
\hline & \multicolumn{4}{|c|}{1988} & \multicolumn{4}{|c|}{1989} \\
\hline & \multirow{2}{*}{$\begin{array}{c}\text { Total DM } \\
(\mathrm{t} / \mathrm{ha})\end{array}$} & \multicolumn{3}{|c|}{ Proportion } & \multirow{2}{*}{$\begin{array}{c}\text { Total DM } \\
(\mathrm{t} / \mathrm{ha})\end{array}$} & \multicolumn{3}{|c|}{ Proportion } \\
\hline & & Stem & Leaf & Head & & Stem & Leaf & Head \\
\hline $\begin{array}{l}\text { Barley } \\
\text { Wheat }\end{array}$ & $\begin{array}{l}1.06 \\
0.97\end{array}$ & $\begin{array}{l}0.38 \\
0.46\end{array}$ & $\begin{array}{l}0.57 \\
0.50\end{array}$ & $\begin{array}{l}0.05 \\
0.04\end{array}$ & $\begin{array}{l}0.35 \\
0.39\end{array}$ & $\begin{array}{l}0.37 \\
0.28\end{array}$ & $\begin{array}{l}0.40 \\
0.26\end{array}$ & $\begin{array}{l}0.23 \\
0.46\end{array}$ \\
\hline
\end{tabular}


Table 2 Contents $(\mathrm{g} / \mathrm{kg})$ and yiclds of digestible organic matter in the dry matter (DOMD) and crude protein (CP) (kg/ha) for barley and wheat stubbles in 1988 and 1989

\begin{tabular}{|c|c|c|c|c|c|c|c|c|}
\hline & \multicolumn{4}{|c|}{1988} & \multicolumn{4}{|c|}{1989} \\
\hline & \multicolumn{2}{|c|}{$\begin{array}{c}\text { Contents } \\
(\mathrm{g} / \mathrm{kg})\end{array}$} & \multicolumn{2}{|c|}{$\begin{array}{l}\text { Yields } \\
\text { (kg/ha) }\end{array}$} & \multicolumn{2}{|c|}{$\begin{array}{c}\text { Contents } \\
(\mathrm{g} / \mathrm{kg})\end{array}$} & \multicolumn{2}{|c|}{$\begin{array}{l}\text { Yields } \\
\text { (kg/ha) }\end{array}$} \\
\hline & DOMD & $\mathrm{CP}$ & DOMD & $\mathrm{CP}$ & DOMD & $\mathrm{CP}$ & DOMD & $\mathrm{CP}$ \\
\hline $\begin{array}{l}\text { Barley } \\
\text { Wheat }\end{array}$ & $\begin{array}{l}372 \\
288\end{array}$ & $\begin{array}{l}31.8 \\
27.7\end{array}$ & $\begin{array}{l}394 \\
297\end{array}$ & $\begin{array}{l}33.9 \\
26.9\end{array}$ & $\begin{array}{l}415 \\
479\end{array}$ & $\begin{array}{l}49.3 \\
63.7\end{array}$ & $\begin{array}{l}142 \\
187\end{array}$ & $\begin{array}{l}16.9 \\
24.9\end{array}$ \\
\hline
\end{tabular}

lower total production of nutrients, except for total production of $\mathrm{CP}$ for wheat.

The rates of disappearance of both leaf and stem DM from the polyester bags were significantly greater in 1989. There were significant differences $(P<0.05)$ between varieties in the disappearance of the leaf fraction at each collection period but the differences between the parameters $a, b$ and $c$ were not significant. The stem fractions showed significant differences in disappearance and in the parameters $a$ and $b$ between varieties (Table 3 ).

Table 3 Degradation of stem fraction in stubble at $48 \mathrm{~h}(\mathrm{~g} / 100 \mathrm{~g})$ and parameters $a, b$ and $c t$

\begin{tabular}{|c|c|c|c|c|}
\hline \multirow[b]{2}{*}{ Variety } & \multirow[b]{2}{*}{$48 \mathrm{~h}$} & \multicolumn{3}{|c|}{ Parameters } \\
\hline & & $a$ & $b$ & $c$ \\
\hline $\begin{array}{l}\text { A. Abaid } \\
\text { Beecher } \\
\text { C-63 } \\
\text { ER/Apam } \\
1988 \\
1989 \\
\text { Significance of variety }\end{array}$ & $\begin{array}{l}38.9 \\
32.1 \\
36.4 \\
37.7 \\
29.8 \\
42.8 \\
* * *\end{array}$ & $\begin{array}{r}0.8 \\
2.3 \\
6 \cdot 3 \\
1.5 \\
-0.4 \\
5.8 \\
*\end{array}$ & $\begin{array}{l}45 \cdot 5 \\
36 \cdot 0 \\
36 \cdot 1 \\
43 \cdot 9 \\
34 \cdot 3 \\
46 \cdot 4 \\
4 * 4\end{array}$ & $\begin{array}{l}0.037 \\
0.043 \\
0.037 \\
0.037 \\
0.041 \\
0.036\end{array}$ \\
\hline
\end{tabular}

+ Fitted values using the equation: $y=a+b\left(1-\mathrm{e}^{-c t}\right)$. 